Vol. 3, No. 1, 2021

https://doi.org/10.23939/jtbp2021.01.042

Orest Voznyak, Khrystyna Myroniuk, Iryna Sukholova, Oleksandr Dovbush, Mariana Kasynets

\title{
PHYSICAL MODELS OF VENTILATION SYSTEM FITTINGS IN SPECIAL CONDITIONS
}

\author{
Lviv Polytechnic National University, \\ Department of Heat and Gas Supply and Ventilation \\ orest.voznyak@i.ua
}

(C) Voznyak O., Myroniuk Kh., Sukholova I., Dovbush O., Kasynets M., 2021

The article presents the formation of physical models of fittings of ventilation systems in the conditions of change of linear sizes and forms of adjacent sections of air ducts of ventilation systems. The aim is to minimize waste materials in the manufacture and sale of pipe billets of different diameters of the ventilation system, reduce metal consumption, increase production productivity and efficiency of procurement for installation of ventilation in industrial premises, identify ways to improve the installation of ventilation in industrial premises for various purposes and justification calculation methods. The use of the obtained physical models to determine the required parameters in the manufacture of sweeps of ventilation system fittings can significantly increase the efficiency criteria for procurement and installation work.

Key words: procurement work, installation work, physical model, fittings, ventilation system, cutting, change-over, air distribution.

\section{Introduction}

The physical state of the air space in the industrial rooms is characterized by different indoor climate characteristics that are maintained by a system of ventilation (Deshko \& Buyak, 2016; Gumen et al., 2016). Comfort conditions at first are determined by the air velocity and internal temperature (Dovhaliuk \& Mileikovskyi, 2007; Voznyak et al., 2005). These values are supported by ventilation devices and depend on the designed structure both of air exchange and air distribution schemes (Dovhaliuk \& Mileikovskyi, 2008; Voznyak et al., 2019). Normalized characteristics of indoor air must be provided in the working area of industrial premises, since the fact that the sanitary-hygienic characteristics of the room microclimate of the industrial rooms correspond to the physiological needs of a person depends, to a large extent, on its health and efficiency (Dovhaliuk \& Mileikovskyi, 2013; Voznyak et al., 2005). In this case, the working area is situated both in the direct and in the return air stream of the incoming airflow. The combination of all actors determines the nature of the airflow at its leakage in a premise (Kapalo et al., 2018). $\mathrm{CO}_{2}$ concentration in a premise also must be taken into account (Kapalo et al., 2019; Kapalo et al., 2014).

To implement these tasks there is a need to increase the efficiency of installation of ventilation in production facilities, increase profits for procurement and installation companies in the manufacture and sale of pipe billets of different diameters of ventilation, identify ways to improve the installation of ventilation in small production facilities and justification calculation.

\section{Target of this article}

The aim is to minimize waste materials in the manufacture and sale of pipe billets of different diameters of the ventilation system, reduce metal consumption, increase production productivity and 
efficiency of procurement for installation of ventilation in industrial premises, identify ways to improve the installation of ventilation in industrial premises for various purposes and justification calculation methods.

\section{Techniques used}

The importance of providing normalized characteristics of the room microclimate due to low gabarites and presence of technological equipment as well maintenance personnel in the industrial premise on air velocity distribution and their features are researched in (Gumen et al., 2016; Dovhaliuk \& Mileikovskyi, 2007; Dovhaliuk \& Mileikovskyi, 2008). It is known for example air distributors with a high intensity of the velocity and temperature extinguishing of the incoming air, that is, devices that provide an intense mixing of the tidal air with the environment (Dovhaliuk \& Mileikovskyi, 2013; Voznyak et al., 2019). It is a great number of different designs of the air distribution devices and circuits of incoming air distribution, both in the upper and in the room serviced area, where the effect of the jets laying on the interior surfaces of walls or ceilings, which is a fairly widespread phenomenon in ventilation technology (Voznyak et al., 2005). We perform the marking of change-overs.

\section{Change-over from rectangular to round section (boot)}

Construct a frontal projection of the change-over with the side of the rectangle $E$, height $H$, and diameter $D$ (Fig. 1, $a, b$ ). According to the frontal projection, we construct a plan of this change-over, in which the smaller side of the rectangle $F$ is indicated. On the central axis we draw a circle with a diameter $D$. As can be seen on the plan, the change-over has a symmetrical shape. That is why, as a basis for marking, we take $1 / 4$ of the change-over, $1 / 4$ of the circle, divide it into three parts, we get points 1-2-3-4. We connect these points with point $B$, we get its generators $A-4, B-4, B-3, B-2, B-1$. Since these generators in the plan are not real values of generators, on which we will build a scan, we determine their real value, for which the radius $B-4, B-3, B-2, B-1$ draw arcs to the intersection with the side $B-C$. The points of intersection, respectively, denote $1^{\prime}-2^{\prime}-3^{\prime}-4$. Next, take segment $\underline{A}-4$, determine their actual value.
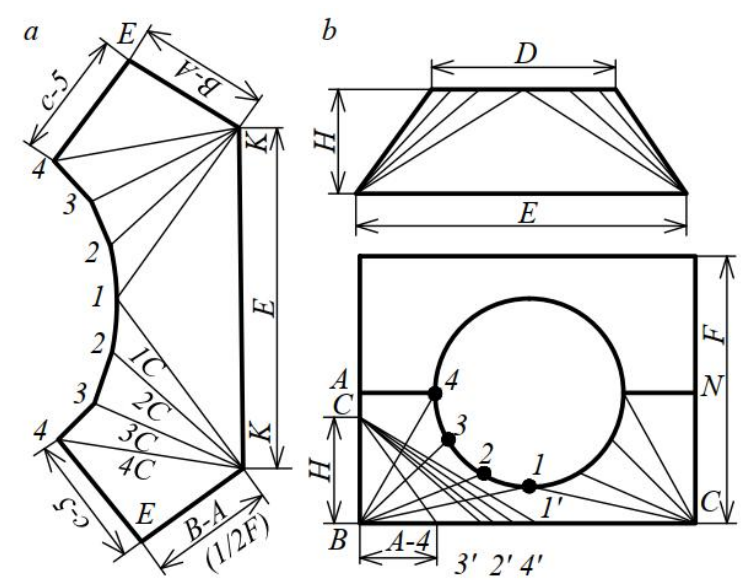

Fig. 1. Construction of an change-over scan from a rectangular to a round section

To do this, segment $A-4$ is set aside from point $B$ (on line $B-C$ ) and denoted by the number 5 . From point $B$ on the side $B$ - $A$ we set aside the height of a given change-over $A$, denoted by point $C$, connect point $C$ with points $1^{\prime}-2^{\prime}-3^{\prime}-4^{\prime}$ and point 5 with point $C$, we obtain the actual values of all generators, on which we build a scan. Draw a straight line $E$ (larger side of the rectangle). Next, from the points $K^{\prime}$ and $K$ we draw arcs $C-2, C-3, C-4$, and from point $l$ we draw arcs equal to $1 / 12$ of the chord of the 
circle $D$ (Fig. 1). At the intersection with the previously drawn arcs, we obtain points 2-2. C points 2-2 draw arcs chords, get points 3-3. Repeating the same from points 3-3, we get points 4-4. From points 4-4 draw arcs equal to the segment $C-5$ (Fig.1), and from the points $K^{\prime}-1$ and $K-1$ of the arc, which is equal to the segment $B-A$ ( $1 / 2$ of the smaller side of the rectangular base). We obtain the points $E$. By connecting the points $K^{\prime}$ and $K$ alternately with the points $E-4-3-2-1-2-3-4-E-K^{\prime}$, we obtain the contour of the scan $1 / 2$ of a given adapter, which is crossed out the second half (Fig. 1).

\section{Change-over from rectangular to round with radii (symmetrical)}

Fig. 2, $a, b$ shows three views of the change-over (front, side view, and plan) with a rectangular base of sides $A$ and $B$, diameter $d$ and height $H$. Construction of the scan is carried out as follows: let $A=500 \mathrm{~mm}$, $B=700 \mathrm{~mm}, d=300 \mathrm{~mm}, \quad H=400 \mathrm{~mm}$. Folding the perimeter of the sides, we obtain: $500+500+700+700=2400 \mathrm{~mm}$. Divide the resulting number $2400 / \pi$, get $2400: 3.14=796 \mathrm{~mm}$ (rounded tenths). The resulting size of $796 \mathrm{~mm}$ is taken as the diameter of the cone of the lower base instead of rectangular.

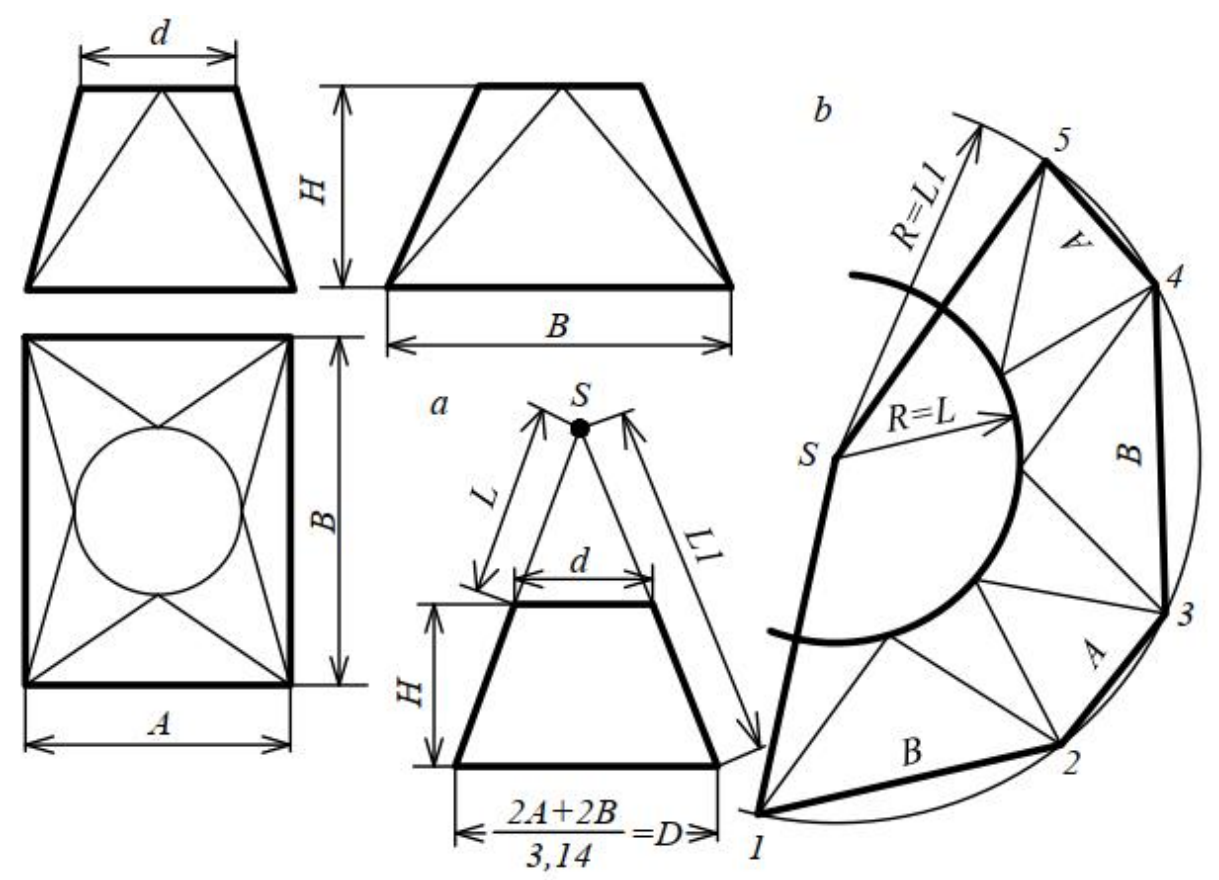

Fig. 2. Construction of an change-over scan from a rectangular base to a round one using radii (symmetrical)

Draw the cone shown in Fig. 2, $a$ in which the diameter of the lower base will be $D=796 \mathrm{~mm}$, the upper base $d=300 \mathrm{~mm}$ and the height $H=400 \mathrm{~mm}$. Having constructed the cone according to the given sizes and having extended its inclined generators to their section on an axial line in a point $S$, we receive the radius of arches of a cone $L$ and $L 1$. To construct a scan (Fig. 2, b) draw an arc of radius $L 1$ from point $S$, connect a straight starting point on the arc (point 1 ). Take the size of side $B$ with a compass and put it on the arc (point 2), from point 2 put the size of side $A$ (point 3 ), from point 3 - size $B$ (point 4 ), and from point $4-\operatorname{size} A$ (point 5). By connecting point 5 with the center $S$, we obtain a full scan of the transition, in which the lower base will be rectangular. After drawing the second $\operatorname{arc} R=L$, we obtain a round base of diameter $d$ and a given height $H$.

Fig. 3, $a, b, c$ shows the plan of the specified change-over and its side view. Construct a square (or rectangle) on the given sides $A B-B C-C D-D A$. According to the required set values of the displacement of the circle $K$ and $K 1$, draw a circle, divide it into 12 parts; from the points of division $1-2, \ldots, 12$ draw 
straight lines to the vertex of the rectangle $A: 1-A, 2-A, 3-A$, to the vertex $B: B-4, B-5, B-6, B-7$, to the vertex $C: C-7, C-8, C-9, C-10$, to the vertex $D: D-10, D-11, D-12, D-1$. Connect point 1 with point $E$, point $F$ with point 7 . We obtain in this way the contour generators (Fig. 3). We determine their real values. On the segment of the horizontal line from point 0 we restore the perpendicular to the given height $H$ (Fig. 3). On the horizontal line from point $O$ we set aside the dimensions of the generators from the plan, and from point $S$ on the vertical line. Measure the length from each deferred point horizontally. We obtain the real values of the generators, with which we build $1 / 2$ of the scan (the area of the square $E-A-B-F$ and the points of the circle 1-2-3-4-5-6-7). We begin the scan with the definition of point 4 , for which we draw a segment of the line equal to the side of the rectangle $A B$. From the diagram (Fig. 3 ) we take the size of the generating $S$ - $A 4$ and draw an arc from point $A$, and the size $S$ - $B 4$ from point $B$ draw an arc to the intersection with the arc drawn from point $A$, we get point 4 (Fig. 3 ).

\section{Change-over from square or rectangular section on round with shift of their axes asymmetrically in all parties}

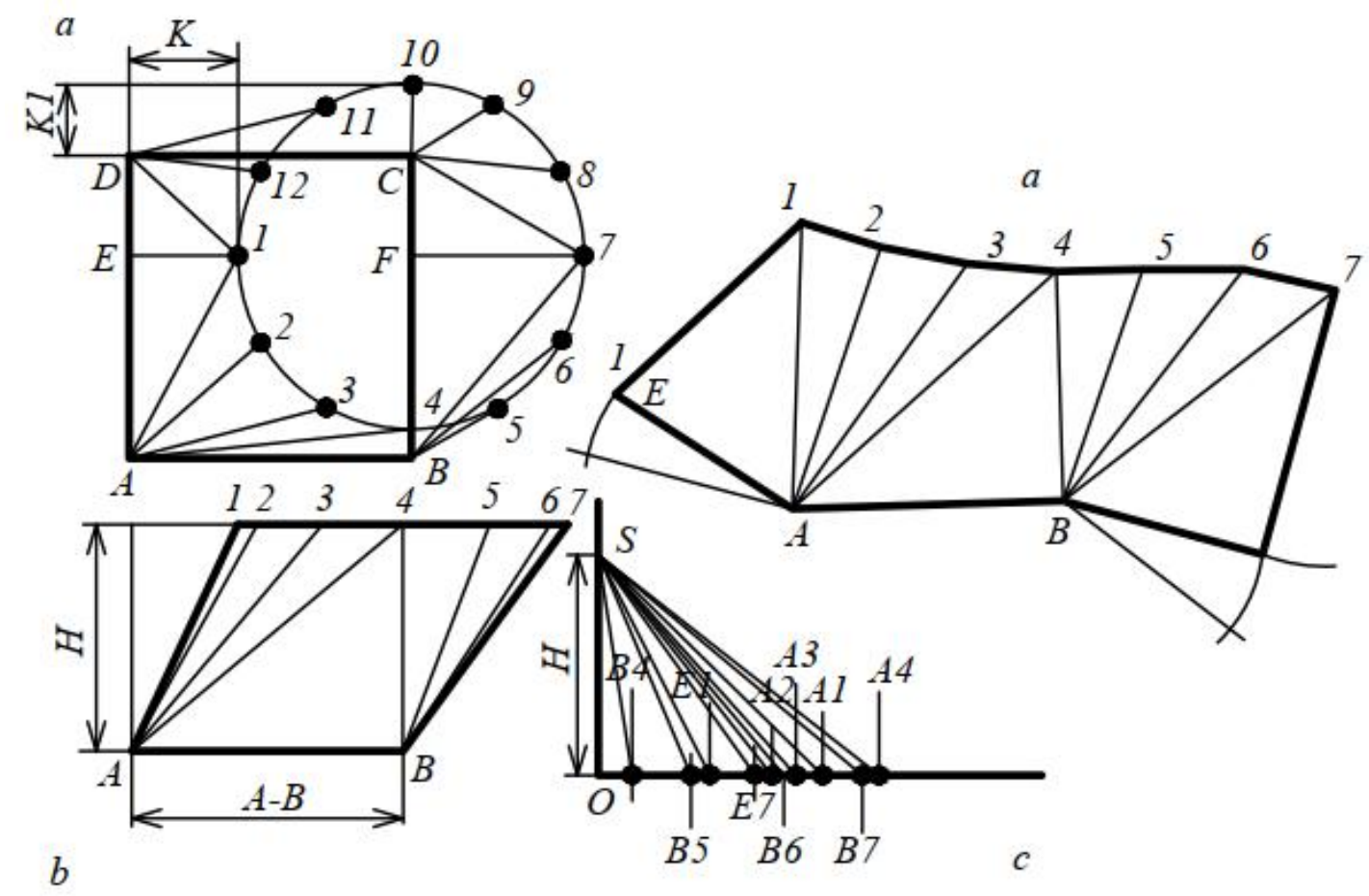

Fig. 3. Construction of scanning of an change-over from square or rectangular section on round with shift of their axes asymmetrically in all parties

Then from point $A$ we draw arcs with radii $S-A 3, S-A 2, S-A 1$, and from point $B$ - arcs with radii $S$-B5, $S$-B6, $S$-B7. From point 4 draw an arc with a radius equal to the chord of $1 / 12$ of a circle, to the intersection with the arcs drawn from points $A$ and $B$, is from the point of intersection 4 to the intersection with the arc 3 , from point 3 to the intersection with the arc 2 , from point 2 to the intersection with the arc 1. In the same sequence, make the intersection of the arcs to the right, we obtain the contour of the sweeping curve $1 / 2$ round base of the transition. After that from point 1 we draw an arc $S$ - $E 1$ (diagram), and from point $A$ an arc $A E$ (plan). From point 7 we draw an arc $S-B 7$ (diagram), and from point $B$ an arc $B F$. By connecting the points of intersection of the arcs with straight lines, we get a full $1 / 2$ scan of the transition from square to circle. Since the second half is asymmetric to the first, it is constructed separately in exactly the same way as the first, with the only difference that the diagram of generators must be constructed separately for it. 


\section{Change-over from square or rectangular section \\ to round, cut non-parallel to the base plane}

Draw a horizontal line $A-B$, equal to the side of the rectangle (Fig. 4). Parallel to it, draw the second line from point $A$ at a given height $H$. From point $B$ we draw the third parallel line at the height $H 1$. From point $A$ we set aside the size $E$, which is equal to the value of the slope of the left generating transition, and restore from the point of the delayed size perpendicular, which intersects a parallel line of height $H$. We obtain point 1 . From point $l$ with a radius equal to the diameter parallel line at the height $H 1$ (point 7), connecting points $1-7-7-B$ and $1-A$, we obtain a frontal projection of the transition, on which we build a plan of the transition. As can be seen from Fig. 4, the transition plan at the base is a rectangle with sides $A B$ and $K M$, which passes to a round upper base with a diameter $D$, the axis of which is offset relative to the rectangular base asymmetrically. Since the round base is cut non-parallel to the plane of the base, the plan will have the shape of an ellipse. Divide the diameter on the frontal projection into six parts, get points $1-2-3-4-5-6-7$. From them, lower the perpendiculars to the plan. Parallel to the side $A B$ we draw a line at a distance $F^{\prime}$, we obtain a point $O$ - the center of the circle of the round base. From point 0 vertically down and up we postpone the sizes $C$ and $C 2$ which are equal: $C=1 / 2 R$ (for any diameter) and $C 2=R \cdot \sqrt{3} / 2 \quad(\sqrt{3}=1.73)$.

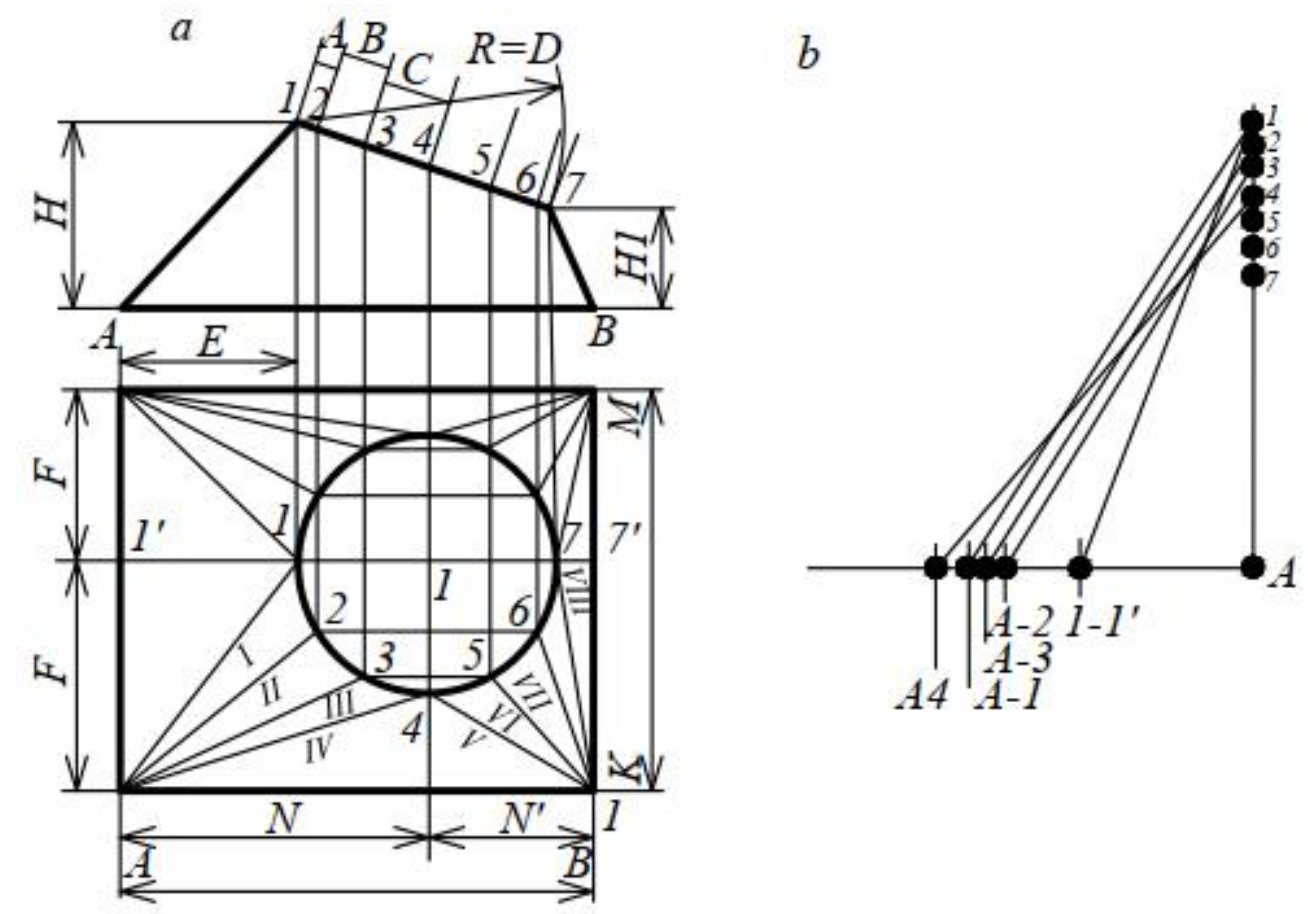

Fig. 4. Construction of an change-over scan from a square or rectangular section to a round, cut non-parallel to the plane of the base

We put the obtained dimensions from the center 0 up and down, draw parallel horizontal lines through them, connecting the points of intersection of vertical and horizontal lines. On the diagonals we find points 1-2-3-4-5-6-7 on the plan (lower half of the adapter on the plan), connect them with the vertices of rectangles $A$ and $B$, as shown in Fig.4. We obtain the generating transitions I-II-III-IV-V-VI and $1^{\prime}-1$, as well as 7-7'. Then you need to determine the true value of these generators. To do this, build a diagram shown in Fig. 4, б. On the horizontal line from the point $A$ we postpone the value of the generators from the plan $1^{\prime}-1, A-1, A-2, A-3, A-4,7-7, B-7, B-6, B-5, B-4$ (the diagram shows only the generators $\left.I^{\prime}-1, I, I I, I I I, I V\right)$. On the vertical line from the same point $A$ we postpone the sizes of heights 
of points 1-2-3-4-5-6-7 from a horizontal line of the bottom basis of transition $A B$ from a frontal projection. By connecting the numbers of the same name horizontally and vertically, we obtain the real values of the generators. In practice, of course, there is no need to connect the horizontal and vertical points of the delayed dimensions, they are measured and immediately the resulting size is applied with chalk to each corresponding product on the plan, which creates convenience and eliminates the possibility of errors in direct scanning.

Construction of the scan (Fig. 4). Draw a line $A-B$, equal to the side of the rectangle of the base. From points $A$ and $B$ we draw arcs equal to the generators $I V$ and $V$, to their mutual intersection (point 4 ). After that we draw arcs equal to generators III-II-I, from point $A$, and from point $B$ arcs equal to generators VI-VII-VIII. Starting from point 4 , the chord $1 / 12$ of the circle of a given change-over draw arcs to the intersection with the arcs of generators. Starting from points 4-3-2 and 4-5-6, from the end points $1-7$ we draw arcs equal to the generators $1^{\prime}-1$ and $7-7^{\prime}$, and from points $A$ and $B$ of the arc equal to $F$. Their mutual the intersection give points $7^{\prime}$ and $l^{\prime}$. By connecting the points $B, 7^{\prime}, 7,6,5,4,3,2,1, l^{\prime}$ and $A$, we obtain a scan contour $1 / 2$ of a given change-over.

In the same way, the second half of the scan is marked with the only difference that the diagram of the actual values of the generators will be different, as can be seen from Fig. 4 (plan), because these values are different.

\section{Change-over from square to round with radii and inscribed in a circle square}
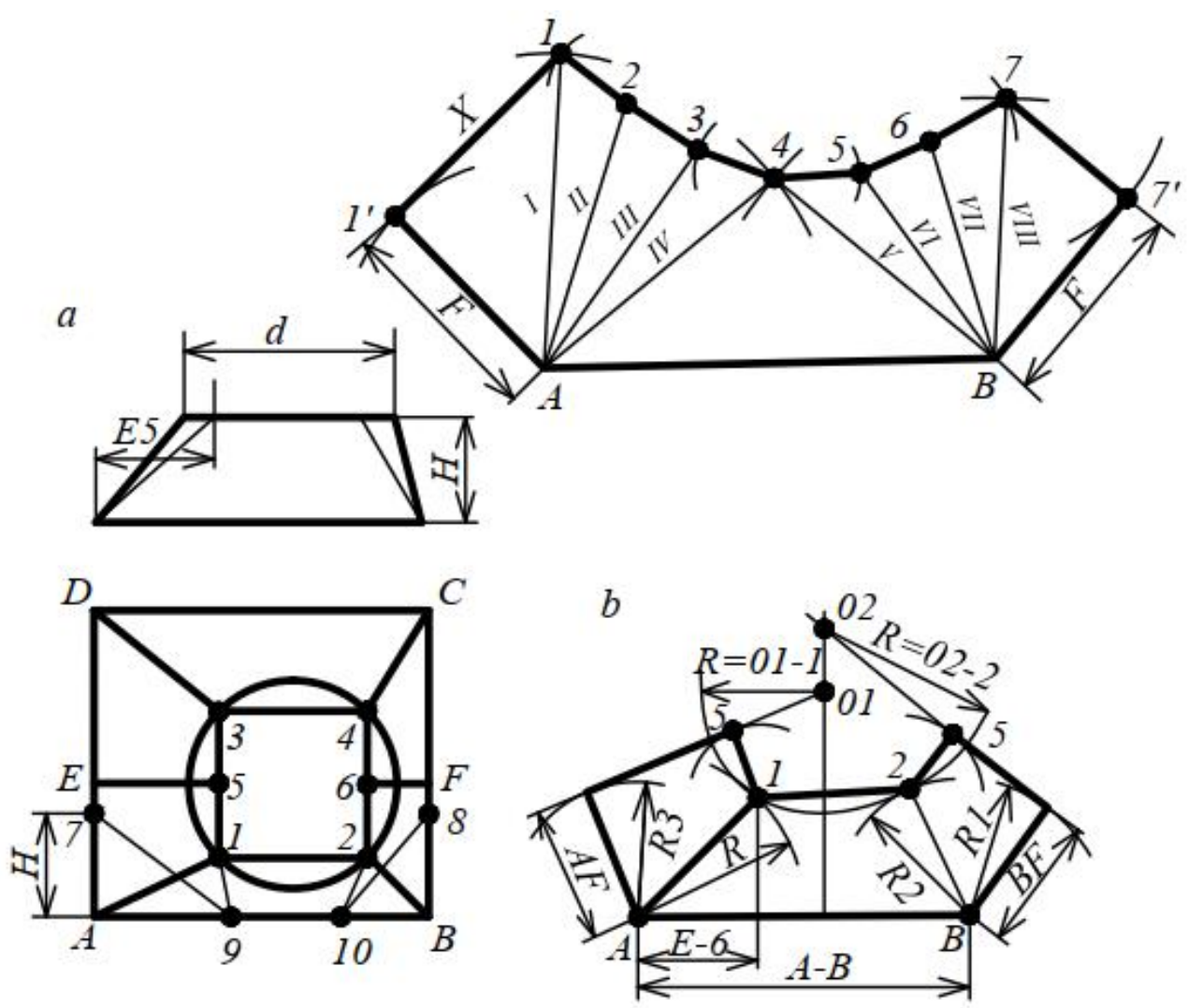

Fig. 5. Construction of an change-over scan from a square section to a round one using radii and a square inscribed in a circle

The scan of the change-over shown in Fig. 5 build in this way. Using the drawing of the plan, on the side $A-D$ from point $A$ we postpone height $H$ (point 7), we do the same from point $B$ (point 8 ). With radius $A-1$ and $B-2$ we draw arcs to the intersection with the side $B$ (points 9 and 10 ). By connecting 
points 7 and 9 and points 10 and 8 , we obtain the real generating edges of the change-over from a rectangular or square section to the inscribed square (edges $A-1$ and $B-2$ ).

Construction of the scan begins with a straight line $A-B$. From point $A$ draw an $\operatorname{arc} R$ equal to the segment 7-9. From point $A$ set aside the value of $E 5$ and restore the perpendicular to the intersection with the $\operatorname{arc} R$ (point 1 ). From point $B$ draw an arc $R 2$ equal to the segment 8 -10. From point 1 draw a line parallel to line $A B$ to the intersection with arc $B 2$ (point 2), connect the line point $1, \mathrm{~A}$ and point 2, B. From points $A$ and $B$ draw arcs $R 3$ and $R l$ equal to the segment $A E$ or $B F$. From points 1 and 2 we draw arcs with a radius equal to the segments $1-5$ and 2-6 (half of the side of the square); to the drawn arcs draw a tangent to the intersection with the perpendicular drawn from the middle of the side of the square. From point 01 we draw an arc equal to $01-1$, to the perpendicular, from point 02 we draw an arc $R$ equal to $02-2$, to the perpendicular. We obtain a rounded contour of the upper circular base. Combining one side of the rectangle with the tangent, and the other with points $B$ and 2 , as well as $A$ and 1 , we obtain a scan of $1 / 2$ of the transition from the rectangle to the circle. The second half of the change-over is built similarly.

\section{Conclusions}

On the basis of the obtained results we state:

- the calculated dependences for the performance of sweeps of fittings of ventilation systems are received;

- technological maps for production of sweeps of fittings of ventilation systems are defined;

- the use of the proposed physical model allows to significantly increase the criteria of efficiency of procurement and installation works and thus reduce the amount of waste and material consumption for the manufacture of ventilation systems.

\section{References}

Deshko, V., \& Buyak, N. (2016). A model of human thermal comfort for analysing the energy performance of buildings. Eastern-European Journal of Enterprise Technologies, Vol. 4, Issue 8-82, 42-48. doi: 10.15587/17294061.2016.74854.

Kapalo, P., Domnita, F., Bacotiu, C., \& Spodyniuk, N. (2018). The impact of carbon dioxide concentration on the human health - case study, Journal of Applied Engineering Sciences, Vol. 8, no. 1, 61-66. ISSN 2284-7197, doi:10.2478/jaes-2018-0008. doi: 10.2478/jaes-2018-0008

Kapalo, P., Meciarova, L., Vilcekova, S., Burdova, E., Domnita, F., Bacotiu, \& C. Peterfi, K. (2019). Investigation of $\mathrm{CO}_{2}$ production depending on physical activity of students. International Journal of Environmental Health Research. Vol. 29, Issue 1, 31-44. ISSN:09603123. doi:10.1080/09603123.2018.1506570.

Kapalo, P., Sedláková, A., Košicanová, D., Voznyak, O., Lojkovics, J., \& Siroczki,P. (2014). Effect of ventilation on indoor environmental quality in buildings. The 9th International Conference "Environmental Engineering”, 22-23 May 2014, Vilnius, Lithuania SELECTED PAPERS, eISSN 2029-7092 / eISBN 978-609-457640-9 Section: Energy for Buildings. doi: 10.3846 / enviro.2014.265.

Kapalo, P., Voznyak, O., Yurkevych, Yu., Myroniuk, Kh., \& Sukholova, I. (2018). Ensuring comfort microclimate in the classrooms under condition of the required air exchange, Eastern European Journal of Enterprise Technologies, Vol 5/10 (95), 6-14. doi: 10.15587/1729-4061.2018.143945.

Kapalo, P., Vilcekova, S., \& Voznyak, O. (2014). Using experimental measurements the concentrations of carbon dioxide for determining the intensity of ventilation in the rooms, Chemical Engineering Transactions, Vol. 39, 1789-1794.ISBN 978-88-95608-30-3; ISSN 2283-9216. doi: 10.3303/CET1439299

Kapalo, P., Vilceková, S., Domnita, F., Bacotiu, C., \& Voznyak, O. (2017). Determining the Ventilation Rate inside an Apartment House on the Basis of Measured Carbon Dioxide Concentrations - Case Study, The 10th International Conference on Environmental Engineering, Vilnius, Lithuania, Selected Papers, 30-35. doi: 10.3846 / enviro.2017.262. 
Voznyak, O., Korbut, V., Davydenko, B., \&Sukholova, I. (2019). Air distribution efficiency in a room by a two-flow device. Proceedings of CEE, Advances in Resourse-saving Technologies and Materials in Civil and Environmental Engineering, Springer, Vol 47, 526-533. doi: 10.1007/978-3-030-27011-7_67.

Voznyak, O., Myroniuk, K., \& Dovbush, O. (2005). Relationship between a Person Heat Exchange and Indoor Climate. Selected scientific Papers 10 th Rzeszow-Lviv-Kosice Conference 2005 Supplementary Issue. Technical University of Kosice.148-152.

Gumen, O. M., Dovhaliuk, V. B., \& Mileikovskyi, V. O. (2016). Determination of the intensity of turbulence of streams with large-scale vortices on the basis of geometric and kinematic analysis of macrostructure. Proc. of Lviv Polytechnic National University: The theory and building practice, No. 844, 76-83 (in Ukrainian).

Dovhaliuk, V.B., \& Mileikovskyi, V.O. (2007). Efficiency of organization of air exchange in heat-stressed premises in compressed conditions, Journal: Building of Ukraine, No. 3, 36 (in Ukrainian).

Dovhaliuk, V. B., \& Mileikovskyi, V. O. (2008). Estimated model of non-isothermal stream, which is laid out on a convex cylindrical surface.Ventilation, Illumination and Heat and Gas Supply: Scientific and Technical Collection, Issue 12, Kyiv, KNUBA, 11-32 (in Ukrainian).

Dovhaliuk, V. B., \& Mileikovskyi, V. O. (2013). Analytical studies of the macrostructure of jet currents for calculating energy-efficient systems of air distribution. Energy efficiency in construction and architecture, Issue 4, $11-32$ (in Ukrainian).

Zhelykh,V. M, Voznyak, O. T, Dovbush, O. M, Yurkevich, Yu. S., \& Savchenko, O. O. (2019).Technologies of procurement and installation of heating and ventilation systems. Lviv: Lviv Polytechnic Publishing House (in Ukrainian).

Zmrhal V., Schwarzer J. (2009). Numerical simulation of local loss coefficients of ventilation duct fittings // Eleventh International IBPSA Conference July 27-30. Glasgow, Scotland, 2009. Vol. I. P. 1761-1766.

Liu, W., Long, Z., Chen, Q. (2012). A Procedure for Predicting Pressure Loss Coefficients of Duct Fittings Using CFD (RP-1493). HVAC\&R Research. 18(6), 1168-1181.

Santos, APP., Andrade, CR., Zaparoli, El. (2014). CFD Prediction of the Round Elbow Fitting Loss Coefficient. International Scholarly Scientific Research \& Innovation. 8(4): 743-747.

Seongjong Park, Yonghwan Park, Bongjae Kim and Jaewoong Choi (2019). A Study on the Dynamic Loss Coefficients of Non-standard Fittings in Ship Exhaust Gas Pipes. Journal of Ocean Engineering and Technology 33(5), 479-485 October, 2019. doi.org/10.26748/KSOE.2019.049.

Mak, Cheuk Ming. (2007). Development of generalized prediction methods for flow-generated noise produced by indoor ventilation systems. Huanan Ligong Daxue Xuebao/Journal of South China University of Technology (Natural Science). 35. 104-107.

Jing, Gang \& Cai, Wenjian \& Cui, Can. (2019). An Energy-saving Model-based Air Balancing Method for the Ventilation System. doi.org/10.11159/cdsr19.124.

G. Jing, W. Cai, D. Zhai, S. Liu, and C. Cui. (2018). A model-based air balancing method of a ventilation system. Energy and Buildings, vol. 174. P. 506-512, 2018.

G. Jing, W. Cai, H. Chen, D. Zhai, C. Cui, and X. Yin (2018). An air balancing method using support vector machine for a ventilation system. Building and Environment. P. 487-495, 2018.

О. Т. Возняк, Х. В. Миронюк, І. Є. Сухолова, О. М. Довбуш, М. Є. Касинець Національний університет “Львівська політехніка", кафедра теплогазопостачання і вентиляції

\title{
ФІЗИЧНІ МОДЕЛІ ФІТІНГІВ ВЕНТИЛЯЦЙНИХ СИСТЕМ У ОСОБЛИВИХ УМОВАХ
}

\author{
(ㄱ Возняк О. Т., Миронюк Х. В., Сухолова I. Є., Довбуш О. М., Касинеиь М. Є., 2021
}

Описано формування фізичних моделей фітингів вентиляційних систем в умовах зміни лінійних розмірів та форми суміжних ділянок повітропроводів систем вентиляції. Отримані результати призначені для застосування на заготівельно-монтажних підприємствах під час виготовлення та реалізації трубних заготовок для монтажу системи вентиляції та кондиціонування у 
виробничому приміщенні. Наведено побудову розгорток фітингів вентиляційних систем для різних вихідних умов, а також запропоновано графічні та аналітичні залежності. Результатами досліджень обгрунтовано отримання мінімальних відходів під час виготовлення та реалізації вентиляційної трубної заготовки різних діаметрів заготівельно-монтажним підприємством. Мета роботи - досягти мінімізації відходів матеріалів під час виготовлення та реалізації трубної заготовки різних діаметрів вентиляційної системи, зменшення металоємності, підвищення продуктивності виробництва та ефективності заготівельних робіт для монтажу системи вентиляції у виробничих приміщеннях, виявити способи підвищення ефективності монтажу системи вентиляції у виробничих приміщеннях різного призначення та обгрунтувати методики розрахунку. Отримані результати дають змогу мінімізувати відходи, за рахунок цього зменшити металоємність матеріалів та підвищити продуктивність виробництва та ефективність заготівельно-монтажних робіт. Застосування отриманих фізичних моделей для визначення необхідних параметрів під час виготовлення розгорток фітингів вентиляційних систем дає змогу значно підвищити критерії ефективності виконати заготівельно-монтажних робіт $\mathrm{i}$ тим самим зменшити витрату матеріалів для виготовлення і монтажу вентиляційної системи.

Ключові слова: заготівельні роботи, монтажні роботи, фізична модель, фітінги, система вентиляції, розгортка, перехідник, повітророзподіл. 